\title{
MATERIAєY
}

\author{
Albin Głowacki \\ https://orcid.org/0000-0002-5207-9449 \\ Wydział Filozoficzno-Historyczny Uniwersytetu Łódzkiego
}

\section{Jak zginął drugi mąż Wandy Wasilewskiej - Marian Bogatko?}

Niespodziewana, tragiczna śmierć Mariana Bogatki we Lwowie w kwietniu 1940 r., jej okoliczności i przyczyny były przez kilkadziesiąt lat w zasadzie tematem tabu. Z powodów politycznych, ale i wobec braku dostępu do odpowiednich źródeł archiwalnych badacze mogli tylko snuć domysły. Prześledzenie skapych wzmianek o tym wydarzeniu w literaturze przedmiotu okresu PRL nasuwa konstatację, że wyjaśnienie śmierci Bogatki sprowadzano do zamachu niezidentyfikowanych sprawców (Polaków lub Ukraińców) na Wandę Wasilewska, którą jakoby zasłonił - i tym samym ocalił - jej mąż. Jednak już w nowej rzeczywistości ustrojowej w Polsce po 1989 r. pojawiły się też i inne sugestie, że oto za zabójstwem Bogatki stały organy Komisariatu Ludowego Spraw Wewnętrznych (NKWD). Ten sensacyjny wątek znalazł potwierdzenie we wspomnieniach ukraińskiego i radzieckiego przywódcy Nikity Chruszczowa (1894-1971). Dopiero jednak dotarcie do odtajnionych akt Resortowego Archiwum Służby Bezpieczeństwa Ukrainy w Kijowie pozwoliło ujawnić dokument, który bezpośrednio dotyczy wyjaśnienia interesującej nas tu kwestii. Poniżej publikuję go więc w całości w polskim przekładzie.

Lekturę tego dokumentu wypada wszakże poprzedzić podstawowymi informacjami na temat Bogatki i jego małżonki, które moga pomóc zrozumieć okoliczności zastrzelenia Bogatki oraz polityczną wagę i skutki tego wydarzenia. 
Żona Mariana Bogatki, Wanda Wasilewska (1905-1964) pozostaje kontrowersyjną postacia. Jej działalność społeczno-polityczna, zwłaszcza w latach okupacji, w momentach przesądzających o losach powojennej Polski, sprawiła, że stała się osoba, o której mówi się i pisze dzisiaj zazwyczaj w bardzo krytycznym tonie. Chodzi głównie o oskarżenia o zdradę Polski i o służbę na rzecz Sowietów, co skutkuje nazywaniem jej renegatka.

Urodziła się w 1905 r. ${ }^{1}$ Pochodziła z zacnej patriotycznej rodziny, która pozostawała wrogo nastawiona zarówno wobec Rosji carskiej, jak i później wobec ZSRR. Ojciec Wandy, Leon Wasilewski (1870-1936) był znanym publicystą i działaczem lewicowym - bliskim współpracownikiem Józefa Piłsudskiego w Polskiej Partii Socjalistycznej (PPS), pierwszym ministrem spraw zagranicznych (1918-1919) odrodzonej Rzeczypospolitej, kierownikiem Instytutu Badań Najnowszej Historii Polski. Matka Wanda z Zieleniewskich (1874-1958) również czynnie uczestniczyła w działalności PPS.

Ich córka Wanda ukończyła studia polonistyczne na Uniwersytecie Jagiellońskim i tam też uzyskała w 1927 r. doktorat. Aktywnie działała w Związku Niezależnej Młodzieży Socjalistycznej (ZNMS) i PPS. 24 II 1925 r. wzięła ślub ze studentem matematyki, działaczem związkowym i aktywista Organizacji Młodzieży Towarzystwa Uniwersytetu Robotniczego (OMTUR) Romanem Szymańskim. Ich małżeństwo przetrwało zaledwie do 8 VIII 1931 r., kiedy to Roman zmarł na tyfus brzuszny. Z tego związku urodziła się w 1928 r. córka Ewa.

Wasilewska pracowała zawodowo od 1927 r. jako nauczycielka, ale jej bardzo aktywne zaangażowanie polityczne po stronie lewicy skutkowało tym, że w 1932 r. nie odnowiono z nią umowy. W poszukiwaniu nowej pracy wyjechała więc w 1934 r. do Warszawy, gdzie dzięki pomocy ojca zatrudniła się w redakcjach „Płomyka” i „Płomyczka” - pism dla dzieci wydawanych przez Zwiazek Nauczycielstwa Polskiego. Publikowała kolejne swoje książki oraz mniejsze teksty w lewicowych tytułach. W stolicy nawiązała szerokie kontakty ze środowiskiem lewicowych literatów, z jednolitofrontowcami z PPS, ale też z komunistami.

Jeszcze w Krakowie jej nowym partnerem życiowym został Marian Bogatko - wtedy już pepeesowiec, „murarz w meloniku”, lider związkowy, działacz Robotniczego Klubu Sportowego „Legia” Kraków, mistrz Polski Robotniczej w podnoszeniu ciężarów²

${ }^{1}$ Szerzej o W. Wasilewskiej zob. m.in.: E. Syzdek, W jednym życiu tak wiele. Opowieść o Wandzie Wasilewskiej, Warszawa 1980; eadem, Działalność Wandy Wasilewskiej w latach drugiej wojny światowej, Warszawa 1981; H. Zatorska, Wanda Wasilewska, Warszawa 1976; A. Ciołkosz, Wanda Wasilewska. Dwa szkice biograficzne, Londyn 1977; Wanda Wasilewska we wspomnieniach, wybór, wstęp i oprac. E. Syzdek, Warszawa 1982; Wspomnienia Wandy Wasilewskiej, „Z Pola Walki” 1968, nr 1, s. 115-195.

2 J. Topiński, Trzy pokoje w Domu Robotniczym na Dunajewskiego 5, w: Cyganeria i polityka. Wspomnienia krakowskie 1919-1939, Warszawa 1964, s. 81. 
Urodził się w 1906 r. w Krzepicach (pow. częstochowski). Bardzo wcześnie osierocony przez ojca, z rodziną wyjechał do Kalisza, a stamtąd kilka lat później do Krakowa. Z powodu trudnych warunków bytowych szkołę ludowa ukończył jako podopieczny klasztoru Karmelitów Bosych we wsi Czerna k. Krakowa. Następnie wrócił do miasta, gdzie w 1919 r. podjął zarobkowanie, zdobywając ostatecznie kwalifikacje murarza (ukończył dwuletnią szkołę zawodowa, co dało mu uprawnienia mistrza). W 1923 r. siedział w areszcie za udział w strajku powszechnym (po raz drugi aresztowany przed wyborami 1930 r.). Aktywnie działał w Związku Robotników Budowlanych (najpierw w oddziale krakowskim, a potem także w centrali). Naturalna koleją rzeczy wstapił do OMTUR (udzielał się w różnorodnych sekcjach i kółkach, był też członkiem ogólnopolskich władz tej organizacji), a następnie został przyjęty do PPS, gdzie związał się z jej lewicowym skrzydłem. Tam spotykał m.in. dr. Bolesława Drobnera (1883-1968) oraz Wandę Wasilewskąa.

Uważa się, że przyjaźń Wasilewskiej i Bogatki, zrodzona na płaszczyźnie działalności politycznej, przekształciła się w trwały związek po tym, jak podczas wspólnej wycieczki kajakowej po Wiśle w $1931 \mathrm{r}$. uratował ją przed utonięciem. Ale ślub (w obrządku kalwińskim) wzięli dopiero w 1936 r. $\mathrm{w}$ okresie przed planowanym wyjazdem do ZSRR (który ostatecznie nie doszedł do skutku) ${ }^{4}$. Zdaniem najbliższej przyjaciółki Wasilewskiej, Janiny Broniewskiej (1904-1981), uchodzili „nie bez racji za jedno z najbardziej udanych małżeństw”.

W 1933 r. Bogatko kierował kilkumiesięcznym strajkiem krakowskich robotników budowlanych, co następnie znalazło odbicie w powieści Wandy Wasilewskiej Oblicze dnia (prototyp Anatola). Adam Ciołkosz (1901-1978) jeden z przywódców PPS - napisał, że Bogatko był „bardzo dobrym typem działacza robotniczego, wysunął się szybko na czoło wśród murarzy, być może w przyszłości rozwinąłby się jeszcze bardziej, lecz albo nie miał po temu danych, albo nie miał okazji” ${ }^{6}$. Według Ciołkosza wspomniany protest robotników budowlanych był „zawzięty, ciężki, długotrwały, lecz wywołany w złym czasie, zakończył się zwycięstwem pozornym, które było jedynie ocaleniem twarzy: stawki godzinowe zostały w umowie zbiorowej podniesione o 1 (jeden) grosz" .

Z kolei Jan Topiński (1907-1971), działacz ZNMS, wspominał, że spotykał Bogatkę - jako jednego z nielicznych robotników - w lektorium Biblioteki Jagiellońskiej, że uczestniczył on w zebraniach kół samokształceniowych młodzieży socjalistycznej, a także kierował referatem robotniczym we wspólnej

\footnotetext{
${ }^{3}$ Stownik biograficzny działaczy polskiego ruchu robotniczego, t. I, Warszawa 1978, s. 203.

${ }^{4}$ Z.A. Woźnicka, O mojej siostrze, w: Wanda Wasilewska we wspomnieniach..., s. 55-56.

${ }^{5}$ J. Broniewska, Tamten brzeg mych lat, Warszawa 1973, s. 127.

${ }^{6}$ A. Ciołkosz, op. cit., s. 12.

7 Ibidem.
} 
warszawsko-krakowskiej redakcji organu wspomnianego Związku - pisma socjalistycznego „Płomienie”8.

Umysł Bogatki również chwalił poeta, prozaik i tłumacz Stanisław Ryszard Dobrowolski (1907-1985), piszac: „Ten murarz z zawodu imponował mi rozległa, wszechstronną wiedzą oraz nieczęsto spotykaną samodzielnością sądów, której mógł mu pozazdrościć niejeden z profesjonalnych intelektualistów"9.

Jan Cegiela (1909-?) opowiadał w 1992 r.: „Mariana Bogatkę znałem doskonale, bo należeliśmy razem do jednego związku zawodowego robotników budowlanych w Krakowie. On był murarzem z zawodu. Był to inteligentny, mądry, bardzo porządny człowiek. Wspaniały mówca"10.

Z kolei Zofia Aldona Woźnicka (1908-1984), młodsza siostra Wandy Wasilewskiej, tak scharakteryzowała swego nowego szwagra: „Marian był wspaniale wysportowanym mężczyzna, o nieprzeciętnej inteligencji i dużej wrodzonej kulturze. Świetny mówca, przy tym niezmiernie łatwo kontaktujący się z ludźmi, uczynny i bezinteresowny - cieszył się ogólną sympatią"11. Potwierdził to też m.in. poeta, prozaik, publicysta, a przed wojną radykalny działacz Stronnictwa Ludowego i ruchu robotniczego Marian Czuchnowski (1909-1991). Pisał o nim: „Miły, rozumny, lubiany powszechnie robotnik krakowski" ${ }^{12}$. Podobnie zapamiętał Bogatkę pisarz, poeta i tłumacz Aleksander Wat (1900-1967): „Fantastyczny atleta, piękny rzeczywiście chłopak, do tańca i do różańca. Bardzo inteligentny, bystry, z poczuciem humoru, szalenie wesoły, silny chłop" ${ }^{13}$. Takie same odczucia miała jego żona, Ola Watowa (1903-1991): „Bogatko, prawdziwy robotnik, przystojny, uczciwy i inteligentny"14.

Wspomniana już pisarka i publicystka Janina Broniewska zanotowała takie oto słowa mecenasa Mieczysława Szerera (1884-1981) o Bogatce: „Cóż za uroczy człowiek! Co za poczucie humoru i jaka błyskotliwa inteligencja...”15 Także Jan Topiński cenił jego „wspaniały, robociarski dowcip” ${ }^{\text {. }}$.

$$
* * *
$$

Po napaści Niemiec na Polskę Wasilewska wraz z mężem opuściła 5 IX 1939 r. Warszawę, kierując się na wschód. Ostatecznie via Chełm dotarli do zajętego już przez Armię Czerwoną Kowla. Stamtąd z Domu Kultury

8 J. Topiński, op. cit., s. 81, 86, 89, 93.

${ }^{9}$ S.R. Dobrowolski, Jaka byta naprawdę?, w: Wanda Wasilewska we wspomnieniach..., s. 111.

${ }_{10}$ Archiwum Wschodnie Ośrodka KARTA, J. Cegiela, Relacja, I/17, s. 3.

${ }_{11}$ Z.A. Woźnicka, op. cit., s. 54.

${ }^{12}$ M. Czuchnowski, Z Moskwy do... Moskwy, Londyn 1945, s. 7.

13 A. Wat, Mój wiek. Pamiętnik mówiony, cz. 1, rozmowy prowadził i przedmową opatrzył

Cz. Miłosz, do druku przygotowała L. Ciołkoszowa, Warszawa 1990, s. 284.

${ }^{14}$ O. Watowa, Wszystko co najważniejsze..., Warszawa 1990, s. 36.

15 J. Broniewska, op. cit., s. 127.

16 J. Topiński, op. cit., s. 89. 
i Wypoczynku przy ul. Limanowskiego 3 napisała 8 X 1939 r. list do Państwowego Wydawnictwa Literatury Pięknej (Goslitizdat) w Moskwie, że zupełnie nie ma środków do życia. Pytała, czy oficyna ta może jej pomóc, gdyż za przekłady książek odebrała poprzez placówkę dyplomatyczną ZSRR w Warszawie tylko część honorariów ${ }^{17}$. Niebawem, wzywana przez radio przez emisariuszy radzieckich władz okupacyjnych, przeniosła się do Lwowa ${ }^{18}$. Urządziła się w willi przy ul. Zadwórzańskiej 49, gdzie od kilku lat mieszkała jej najstarsza siostra Halszka ${ }^{19}$, zaprzyjaźniona z właścicielką tego domu ${ }^{20}$, a gdzie zatrzymali się też inni bliscy znajomi Wandy Wasilewskiej - Szymon i Franciszka Natansonowie ${ }^{21}$. Zdążyła wziąć udział $\mathrm{w}$ farsie wyborczej do Zgromadzenia Ludowego Zachodniej Ukrainy (głosowanie 22 października), które zebrało się we Lwowie (26-28 X 1939 r.), aby m.in. proklamować władzę radziecką na okupowanym terytorium i wystapić z prośbą o przyłączenie Zachodniej Ukrainy do ZSRR.

Od początku pobytu na zajętych przez Armię Czerwoną ziemiach wschodnich II RP Wasilewska jednoznacznie i bardzo aktywnie opowiedziała się po stronie władz okupacyjnych ${ }^{22}$, publikowała w lwowskiej, republikańskiej oraz centralnej prasie radzieckiej, agitowała, przekonywała, że „Zachodnia Ukraina rozpoczyna nowe, szczęśliwe, wolne życie"23. Stwierdzenie to kłóciło się z codziennością znaczoną m.in.: odgórnymi, radykalnymi przemianami społeczno-gospodarczymi na modłę radziecka, coraz szerszymi represjami wobec patriotycznego, narodowego żywiołu, strachem, cenzura, inwigilacja, kłopotami aprowizacyjnymi, ograniczaniem polskości.

Kolaboracja Wasilewskiej z Sowietami została przez nich szybko doceniona: z nadania Józefa Stalina nominowali ją na kandydatkę w „wyborach”

${ }_{17}$ Rossijskij gosudarstwiennyj archiw litieratury i iskusstwa, fond 2550, opis 2, jed. chr. 116, List z 8 X 1939 r., k. 1-2.

${ }^{18}$ Wspomnienia Wandy Wasilewskiej (1939-1944), „Archiwum Ruchu Robotniczego” 1982, [t.] VII: W 40 rocznice powstania Polskiej Partii Robotniczej, s. 345.

19 Halina (Halszka) Wasilewska (1899-1961), w przeciwieństwie do swej siostry Wandy, była podczas II wojny światowej uczestniczka niepodległościowego nurtu ruchu oporu (SZP-ZWZ-AK). W okresie międzywojennym bardzo aktywnie pracowała w Przysposobieniu Wojskowym Kobiet. Po zajęciu Lwowa w 1939 r. przez Sowietów zaprzysiężona (ps. Krystyna) w tamtejszym okręgu Służby Zwycięstwu Polski (SZP). W listopadzie 1940 r. ściagnięta przez Marię Wittek (1899-1997) do Warszawy, gdzie kontynuowała działalność konspiracyjna. Aresztowana (1943) i więziona przez Niemców - umieszczona najpierw na Pawiaku, a następnie (w kwietniu 1944 r.) w obozie Ravensbrück, gdzie doczekała wyzwolenia. W Armii Krajowej (AK) uzyskała stopień majora. Zmarła na emigracji w Londynie. Zob. https://kpbc.ukw.edu.pl/Content/201588/Wasilewska_Halina_366_WSK.pdf (dostęp: 10 VII 2020).

${ }^{20}$ Z.A. Woźnicka, op. cit., s. 68-69.

${ }^{21}$ Wspomnienia Wandy Wasilewskiej..., s. 355.

${ }^{22} \mathrm{O}$ tym etapie jej życia szeroko m.in. E. Syzdek, Działalność Wandy Wasilewskiej..., passim.

${ }^{23}$ W. Wasilewskaja, Tri dnia, „Prawda”, 31 X 1939, s. 2. 
uzupełniających do Rady Najwyższej ZSRR i dzięki temu w końcu marca 1940 r. uzyskała mandat deputowanej. Oznaczało to dla niej ogromny, prestiżowy awans w hierarchii politycznej ważności i wyniesienie przez okupanta na pozycję liderki mniejszości polskiej na zaanektowanym przez ZSRR terytorium II Rzeczypospolitej.

Ale już miesiąc później ten nastrój sukcesu zmienił się diametralnie: w nocy z wtorku na środę 23/24 IV 1940 r. „nieznani sprawcy” zastrzelili jej męża...

Choć śmierć Bogatki stała się - nie tylko we Lwowie - głośnym wydarzeniem, swego rodzaju sensacja, to jednak nie znalazła odbicia choćby w formie wzmianek w miejscowej prasie codziennej (polskojęzycznej, ukraińskiej i rosyjskojęzycznej). Nie opublikowano w niej także nekrologów czy kondolencji dla Wasilewskiej. Władze bezpieczeństwa nie ogłosiły apelu o pomoc w znalezieniu sprawcy(-ów) mordu. Można domniemywać, że stało się tak m.in. ze względu na dążenie do wyciszenia tej sprawy oraz zapewne dlatego, ażeby nie zakłócać atmosfery przygotowań do świętowania zbliżających się uroczystości pierwszomajowych. Ponadto - po niedawnej (drugiej już) wywózce na zsyłkę z zaanektowanych ziem II RP w głą ZSRR ponad 60 tys. obywateli polskich (13 IV 1940 r.) - zabójstwo Bogatki mogło kojarzyć się z zemstą na Sowietach i ich politycznych wspólnikach/ kolaborantach choćby za tę akcję deportacyjna.

Warto więc w tym miejscu zacytować fragment wspomnień ówczesnego mieszkańca Lwowa, Jana Rogowskiego, który w zapiskach wzmiankował także o pogrzebie Bogatki: „W sobotę 26 kwietnia ${ }^{24}$ przed południem odbył się pogrzeb - podobno męża Wasilewskiej, deputatki do «Werhownych Rad», którego - jak opowiadano w mieście - mieli zastrzelić Ukraińcy czy inni «przyjaciele». Krążyły pogłoski, że był to zamach wykonany przez bojówkę polską na samą Wasilewską. Ofiara padł jednak jej mąż, który otworzył drzwi mieszkania przy ulicy Murarskiej ${ }^{25}$. Do niego przez uchylone drzwi oddano strzały, a Wanda Wasilewska ocalała. Auto, którym wieziono zwłoki w odkrytej trumnie, było obite czerwonym suknem; obok szła milicja” ${ }^{26}$.

Podobnie opowiadał po latach inny ówczesny mieszkaniec Lwowa - Jan Cegiela (uchodźca z Krakowa): „Widocznie ten zamach - tak ja myślę - był na nią [Wandę Wasilewska]. Chcieli ją zabić. Ale on [Bogatko] otworzył drzwi i [...] został zastrzelony. [...] Z tego, co mówiono wtedy we Lwowie, albo to zrobili ukraińscy nacjonaliści, [...] albo pewne ugrupowanie nawet polskie. Jako protest przeciwko temu, że ona została deputatem Wierchownego Sowieta. Ale muszę powiedzieć o Wandzie Wasilewskiej: Ja ją znam z Krakowa jako

\footnotetext{
2426 IV 1940 r. był piątek.

${ }^{25}$ Błędna informacja. Już po śmierci Bogatki Wasilewska przeprowadziła się z ul. Zadwórzańskiej, ale do mieszkania przy ul. Zielonej. Z.A. Woźnicka, op. cit., s. 70.

${ }^{26}$ Zakład Narodowy im. Ossolińskich, Rękopisy, 16709/II, J. Rogowski, „W czerwonym Lwowie. Wspomnienia z czasów wojny i okupacji” 1939-1941, k. 123.
} 
bardzo, bardzo porządnego człowieka. [...] Było w ogóle dla mnie dziwne, że ona była tym deputatem" ${ }^{27}$.

Sprawa nagłej śmierci jej męża stała się tematem wielu rozmów, komentarzy, domysłów. Gustaw Herling-Grudziński (1919-2000), który w 1940 r. przebywał we Lwowie (,zamieszany w jakaśs konspiracyjną robotę”), zapamiętał, że w tym „sowieckim, sterroryzowanym” mieście słyszał „niemal codziennie na różnych kwaterach tę samą "zbitkę». Składała się z trzech członów. [...] W drugim była mowa o zastrzeleniu robotniczego księcia małżonka [Wasilewskiej], przy czym w tej wersji wiecznie pijany Bogatko rozstał się z życiem nie jako bołtun ${ }^{28}$, lecz jako swoisty środek profilaktyczny zaaplikowany żonie: żeby jej się w głowie nie przewróciło, żeby wiedziała, z kim zawiera nierozerwalny ślub polityczny" 29 .

Natomiast cytowany już tu Ciołkosz zapamiętał, że „Bogatko zachowywał się we Lwowie tak samo, jak przedtem w Krakowie i Warszawie: chodził, gdzie chciał i mówił, co myślał. Nie żył w stanie euforii, jak jego żona; miał oczy otwarte, interesował się położeniem robotników i widział, że jeśli chodzi o ochronę pracy, ubezpieczenia społeczne i uprawnienia związów zawodowych - sytuacja uległa znacznemu pogorszeniu w porównaniu z sytuacja w «pańskiej Polsce»; toteż kręcił nosem na nową rzeczywistość. Zapłacił za to życiem" ${ }^{30}$.

Radziecka przyjaciółka i biografka Wasilewskiej, Helena Usijewicz (18931968), w wydanej w 1953 r. książce na temat jej twórczości, bardzo lakonicznie odnotowała, że „Marian Bogatko został zdradziecko zabity przez kontrrewolucyjną bandę w 1940 roku" ${ }^{31}$.

Zdecydowanie szerszymi informacjami o tym tragicznym wydarzeniu miała szansę podzielić się najbardziej zainteresowana (czyli żona zastrzelonego) podczas swego pobytu w Warszawie w styczniu $1964 \mathrm{r}$. Zaproszona z inicjatywy doc. dr. hab. Feliksa Tycha (1929-2015) gościła wówczas w Zakładzie Historii Partii przy Komitecie Centralnym (KC) Polskiej Zjednoczonej Partii Robotniczej i odpowiadała na pytania przygotowane przez jego pracowników. Ale, jak po latach przyznał Tych, „o tematach wstydliwych, jak pomoc gestapo w połączeniu z córką czy zabójstwo męża, nie opowiadała, a nikt z nas nie ośmielił się zapytać”32. Szkoda...

Nie znajdujemy na ten temat nowych faktów i komentarzy także w opracowaniu Heleny Zatorskiej o Wandzie Wasilewskiej. W książce tej (opublikowanej

\footnotetext{
${ }_{27}$ Archiwum Wschodnie Ośrodka KARTA, J. Cegiela, Relacja, I/17, s. 2-3.

${ }_{28} \mathrm{Tu}$ w znaczeniu papla, gaduła.

${ }_{29}$ G. Herling-Grudziński, Dziennik pisany noca 1973-1979, Warszawa 1995, s. 269.

${ }^{30}$ A. Ciołkosz, op. cit., s. 25.

31 Je. Usijewicz, Wanda Wasilewskaja. Kritiko-biograficzeskij oczerk, Moskwa 1953, s. 18.

32 J. Szczęsna, Portret Wandy Wasilewskiej, https://wyborcza.pl/1,153803,301460.html (dostęp: 4 VIII 2020).
} 
niemalże pół wieku temu) zamieszczona została w przypisach następująca informacja o śmierci Bogatki: „Zginą tragicznie we Lwowie, zasłaniajac żonę przed kulą zamachowca w 1940 r. Skomplikowane okoliczności napadu, a później [po ponad roku! - A.G.] wybuch wojny radziecko-niemieckiej spowodowały, że ani morderca, ani jego inspiratorzy nie zostali zidentyfikowani" ${ }^{33}$.

Zofia Aldona Woźnicka, siostra Wasilewskiej, od jesieni 1939 r. przebywająca z mężem (kierownikiem szkoły kolejowej) w Kowlu, z powodów rodzinnych należała do osób zapewne najlepiej poinformowanych o okolicznościach zastrzelenia szwagra. W lecie 1940 r. przeniosła się do Lwowa i zamieszkała przy ul. Zadwórzańskiej w pobliżu obu swoich sióstr, co stwarzało im możliwości częstszych rozmów. Na początku lat osiemdziesiątych XX w. tak opisywała interesujace nas wydarzenie: „Z końcem kwietnia 1940 roku otrzymałam wiadomość o tragicznej śmierci Mariana Bogatki. Dostał śmiertelny postrzał przez oszklone drzwi wejściowe z rąk nieznanych osobników, gdy odmówił wpuszczenia ich do domu. Zmarł w szpitalu, przewieziony tam przez wezwane pogotowie. Sprawa tego zabójstwa nie została nigdy do końca wyświetlona. Istniały różne wersje. Według wersji, która dotarła do mnie wówczas do Kowla, był to zamach na Wandę, organizowany względnie inspirowany, jak sądzono, przez nacjonalistów ukraińskich. Później słyszałam też inną wersję, że obiektem zamachu nie była Wanda, lecz właśnie Marian" ${ }^{34}$.

Chociaż mówiło się o „nieznanych sprawcach”, to Wat, który we wrześniu 1939 r. uciekł do zajętego przez Sowietów Lwowa (sympatyk komunizmu), gdzie niebawem utracił wolnośćc ${ }^{35}$, miał bardziej konkretne informacje. Wspominał: „Już w więzieniu przyszedł do celi Ukrainiec, który mi opowiadał o śmierci Bogatki, wariant potwierdzony przez [Władysława] Broniewskiego. Dwaj enkawudyści przyszli do domu i zastrzelili go. Przy czym w dziejach kryminologii sowieckiej fakt chyba bez precedensu, mianowicie sprawców nie znaleziono [...], nikogo; w gazetach tłumaczono, że zabili go ukraińscy nacjonaliści. [...] Broniewski zreszta, który z Wandą [Wasilewska] utrzymywał ciagle, do końca bliskie, dobre stosunki, potwierdził mi, że to jest fakt - zastrzelili go enkawudyści. [...] To jest prawdziwa, świetna szkoła stalinowska, żeby [Wasilewska] nie miała złudzeń. Point de rêveries ${ }^{36}$. Od razu. Jednorazowy szok. Zen ${ }^{37}$. Po łbie i cała zrestrukturalizowana świadomość. Następuje pieriekowka ${ }^{38}$ duszy.

${ }^{33}$ H. Zatorska, op. cit., s. 357.

${ }^{34}$ Z.A. Woźnicka, op. cit., s. 69.

${ }_{35}$ Aleksander Wat był aresztowany przez NKWD 24 I 1940 r. we Lwowie wraz z grupa innych literatów (zatrzymano też Władysława Broniewskiego, Tadeusza Peipera, Anatola Sterna) w restauracji Aronsona, gdzie urządzono prowokację. M. Borwicz, „Inżynierowie dusz”, „Zeszyty Historyczne” (Paryż) 1963, z. 3, s. 134-135.

${ }^{36}$ Point de rêveries - Żadnych mrzonek.

${ }^{37}$ Zen - nurt w buddyzmie; tu: kontrolowanie procesu myślenia, stan najwyższego oświecenia.

${ }^{38}$ Pieriekowka (ros.) - przekuwanie, reedukacja. 
Ale znowu powtarzam: po naszym aresztowaniu Wanda zadała sobie mnóstwo niebezpiecznego trudu, żeby nas wyciagnacc. Chruszczow podobno ją ostrzegł, żeby się nie wtrącała do tego" 39 .

Nurt myślenia swego męża podzielała i Watowa. Napisała, że Wasilewska, która „starała się pomóc [...] żonom aresztowanych pisarzy, wyrażała swoje współczucie i zrozumienie [...], sama w krótkim czasie została pouczona, jak należy się zachowywać". W związku z tym, że Stalin miał wobec niej pewne plany polityczne, „Bogatko [...] stał temu na przeszkodzie, wygłaszając nieraz, i to na głos, krytyczne uwagi na temat tego, co się dzieje [na zaanektowanych przez ZSRR ziemiach wschodnich II RP]. Oczywiście, że mogli jego zaaresztować, jak wszystkich innych, za gadanie [...] rzeczy, których się nie mówi. [...] A Bogatko uważał, że jest w kraju, który należy do niego, i [...] jako proletariusz może wszystko mówić, co on o tym myśli. Ale to nie w niego uderzono, tylko [...] w nią. I od tej pory miała zrozumieć, że jest i musi być narzędziem. I tak już została w Związku [Radzieckim]"40.

Inny znajomy Wasilewskiej, Włodzimierz Sokorski (1908-1999), już po upadku PRL odważył się na takie oto stwierdzenia: „Nie wiem, czy gdyby NKWD nie kropnęło Mariana Bogatko na oczach Wandy Wasilewskiej, jej los potoczyłby się tak, jak się potoczył. Nie usprawiedliwia to ani jej, ani ludzi, którzy z nią współpracowali, lecz wyjaśnia okoliczności wpadnięcia do wirówki. [...] Przyjaźniłem się z jej mężem, Marianem. Ich głęboko patriotyczne postawy $\mathrm{w}$ niczym nie zapowiadały kołowrotu, w jaki ona potem wpadła. Zreszta Bogatko ani przez chwilę nie ufał Sowietom i dlatego NKWD go zlikwidowało” ${ }^{41}$. Według Sokorskiego zabójstwo Bogatki „to był cios, po którym Wanda stała się inna. Radziecka. Gorzej. Serwilistycznie radziecka"42.

Julian Stryjkowski (właśc. Pesach Stark, 1905-1996), który w okupowanym przez Sowietów Lwowie pracował m.in. jako korektor w polskojęzycznym dzienniku „Czerwony Sztandar”, w autobiograficznej powieści Wielki strach odnotował: „Według jednych Bogatko zginą od kuli przeznaczonej dla Wandy Wasilewskiej, według innych - z rąk ukraińskich faszystów albo polskiego podziemia. Byli i tacy, którzy rozsiewali pogłoski, że było to dziełem NKWD" ${ }^{43}$.

Porównując powyższy przegląd wypowiedzi z tym, co po latach ogłosił o zastrzeleniu Bogatki Władysław Gomułka (1905-1982), można odnieść wrażenie, iż wiedział on na ten temat zdumiewajaco mało. A przecież do Lwowa przeniósł się z Białegostoku już w końcu 1939 r. Wspominając ten okres swego życia, tak napisał o Wasilewskiej: „Jak powszechnie sądzono zdobyła sobie szczególne względy u Stalina i z tej racji spełniała nie znana

\footnotetext{
${ }^{39}$ A. Wat, op. cit., t. I, s. $284-285$.

${ }^{40}$ O. Watowa, op. cit., s. 36.

${ }^{41}$ W. Sokorski, Romans z komuna, Łódź 1991, s. 149-150.

${ }^{42}$ Zob. https://pamiec.pl/pa/teksty/artykuly/50116,WASILEWSKA-CELUJACY-Z-ZAPRZANSTWA.html (dostęp: 14 V 2020).

${ }^{43}$ J. Stryjkowski, Wielki strach. To samo, ale inaczej, Warszawa 1990, s. 198.
} 
nam bliżej rolę reprezentantki społeczności polskiej wobec władz radzieckich. Nigdy jednak nie zostało wyjaśnione, ani wówczas, ani w latach późniejszych, tajemnicze zabójstwo jej męża, bodaj robotnika krakowskiego Bogatki, w jej mieszkaniu we Lwowie" ${ }^{44}$.

Najbardziej zdecydowany we wskazaniu inspiratora mordu okazał się dr hab. Adam Sudoł, prof. nadzw. UKW, który stwierdził, że to „na rozkaz komendanta obszaru lwowskiego ZWZ, 26 kwietnia [!] 1940 roku dokonano zamachu na Wandę Wasilewska. Akcja skończyła się niepowodzeniem. Zabito męża Wasilewskiej - Mariana Bogatkę, który nie chciał wpuścić zamachowców do mieszkania" ${ }^{45}$.

Według Stryjkowskiego „odkąd mąż Wandy Wasilewskiej, Bogatko, padł od skrytobójczej kuli, dom deputata Wierchownogo Sowieta ${ }^{46}$ był strzeżony" ${ }^{47}$.

O tym, swego czasu, głośnym zabójstwie był zapewne na bieżąco bardzo dobrze informowany Nikita Siergiejewicz Chruszczow - „gospodarz” Ukraińskiej SRR: I sekretarz KC Komunistycznej Partii (bolszewików) Ukrainy w latach 1938-1949, szef rządu tej republiki związkowej (1944-1947), a następnie najważniejszy funkcjonariusz reżimu - I sekretarz KC Komunistycznej Partii Związku Radzieckiego (1953-1964) oraz przewodniczący Rady Ministrów ZSRR (1958-1964). We wrześniu 1939 r. przeniósł się on z Kijowa do zajętego przez Armię Czerwoną Lwowa (był wtedy także członkiem Rady Wojennej Frontu Ukraińskiego). Tam - wspólnie m.in. z komisarzem ludowym spraw wewnętrznych Ukraińskiej SRR Iwanem Aleksandrowiczem Sierowem (1905-1990) - na miejscu organizowali akcje przeciwko próbom polskiego oporu, nadzorowali instalowanie nowych władz, przebieg „wyborów” do Zgromadzenia Ludowego Zachodniej Ukrainy i jego „obrady”, działali na rzecz pozyskania miejscowej inteligencji itd. Wtedy to Chruszczow poznał Wasilewska. I dopiero on po wielu latach $\mathrm{w}$ swoich wspomnieniach wreszcie odsłonił przebieg tamtego dramatycznego wydarzenia, choć nie zadbał o pełna precyzję wypowiedzi. Oto jego relacja: „Jak cios obuchem w głowę stała się dla mnie wieść, że nasi czekiści zabili męża Wasilewskiej. To było przypadkowe zabójstwo, jak mi uczciwie wyznali. Byłem jednak wstrzaśsnięty. Mąż Wandy Lwowny ${ }^{48}$ należał do PPS, miał robotnicze korzenie, choć działał mniej aktywnie niż ona. Od razu zrodziło się pytanie: jak ta sprawa odbije się na stosunku Wasilewskiej do nas? Czy nie pomyśli, że usunęliśmy jej męża z jakichś powodów politycznych? Różne rzeczy moga przyjść człowiekowi do głowy w następstwie takiej tragedii. Powiedziałem swoim

\footnotetext{
${ }^{44}$ W. Gomułka, Pamiętniki, t. II, red. nauk. A. Werblan, [Warszawa 1994], s. 54-55.

${ }^{45}$ A. Sudoł, Poczqtki sowietyzacji Kresów Wschodnich Drugiej Rzeczypospolitej (jesień 1939 roku). Wybrane problemy polityczne i organizacyjne, Bydgoszcz-Torun 1997, s. 117.

${ }^{46}$ Wierchownyj Sowiet (ros.) - Rada Najwyższa.

47 J. Stryjkowski, op. cit., s. 198.

${ }^{48}$ Wanda Lwowna - Wanda Wasilewska, córka Leona.
} 
Ukraińcom, Korniejczukowi ${ }^{49}$ i Bażanowi ${ }^{50}$ : wytłumaczcie Wandzie Lwownie uczciwie jak to się stało, niczego nie ukrywajcie. A stało się tak. Czekiści chcieli aresztować jakiegoś lokatora domu, w którym mieszkała we Lwowie Wasilewska, ale piętro wyżej. Pomylili mieszkania. Zapukali przypadkiem do innego. Maż Wasilewskiej otworzył drzwi i od razu został zastrzelony. Pytałem potem: «Dlaczego strzelano? Popełniono pomyłkę, zapukali nie do tych drzwi, co trzeba, ale człowiek przecież je otworzył, można było wszystko z nim wyjaśnić». Odpowiedziano mi, że czekistom wydało się, iż lokator był uzbrojony i miał zamiar strzelać. Oczywiście to był akt tchórzostwa ze strony funkcjonariuszy. Mąż Wasilewskiej nie miał broni i nie mógł strzelać. Zabili człowieka i tyle... Opowiedzieliśmy cała prawdę o tym Wandzie Lwownie i poprosiliśmy o zrozumienie. Wasilewska uwierzyła, że nie było w tym przypadku premedytacji i aktywnie pracowała dalej, przyjaźnie do nas nastawiona. Miałem z nią jak najlepsze stosunki do końca jej życia" ${ }^{1}$.

Treść przytoczonych powyżej wypowiedzi różnych osób możemy obecnie skonfrontować z dokumentem archiwalnym na temat zastrzelenia Bogatki, sporządzonym przez funkcjonariuszy resortu spraw wewnętrznych, który to resort okazał się sprawca opisanej tragedii. Publikowany poniżej raport w tej kwestii, firmowany przez szefa ukraińskiego NKWD, adresowany jest do szefa NKWD ZSRR, który wcześniej instruował Kijów co do prowadzenia śledztwa w sprawie śmierci Bogatki. Dokument przedstawia przebieg wydarzeń ustalony na miejscu przez pracowników NKWD delegowanych ze stolicy Ukrainy. Wzgląd na polityczne reperkusje zabójstwa męża Wasilewskiej zapewne wpływał na ostateczne sformułowania raportu. Choć nadano mu klauzulę ścisłej tajności, informacja o przebiegu zdarzenia była, jak to ujawnił Chruszczow, przekazana wdowie. Ale ona nigdy publicznie do tej osobistej tragedii nie odnosiła się. Czy rzeczywiście dała wiarę temu, co ustalili śledczy NKWD? Czy i ewentualnie w jakim zakresie wydarzenie to wpłynęło na jej dalszą działalność? Czy mają rację ci, którzy twierdza, że okazało się ono przełomowym momentem w jej zaangażowaniu w służbie Sowietów i że stała się ich narzędziem?

Funkcjonariusz uznany przez swych służbowych zwierzchników za głównego winowajcę fiaska operacji na ul. Zadwórzańskiej został zwolniony z pracy we Lwowie i... przeniesiony na takie samo stanowisko do Zarządu NKWD $\mathrm{w}$ innym obwodzie, morderca Bogatki zaś trafił do aresztu. Jego dalszych losów i ewentualnego wymiaru kary dla niego nie udało się ustalić.

${ }^{49}$ Aleksandr Jewdokimowicz Korniejczuk (1905-1972) - ukraiński radziecki pisarz i działacz polityczny, przewodniczący Zarządu Związku Pisarzy Radzieckich Ukrainy. W jesieni 1939 r. wysłany do Lwowa z zadaniem pozyskania dla nowej władzy tamtejszych środowisk inteligenckich.

${ }^{50}$ Nikołaj (Mykoła) Płatonowicz Bażan (1904-1983) - ukraiński radziecki poeta, tłumacz, publicysta i działacz społeczny. W jesieni 1939 r. oddelegowany przez władze polityczne w Kijowie do Lwowa w celu dotarcia m.in. do pracowników placówek kultury.

${ }^{51}$ Fragmenty wspomnień N.S. Chruszczowa, „Zeszyty Historyczne” (Paryż) 2000, z. 132, s. 140. 


$$
* * *
$$

Tekst raportu został napisany w języku rosyjskim. Jest to kopia maszynopisowa. Przekładu na język polski dokonał Albin Głowacki. Dla zachowania specyfiki resortowego żargonu pozostawiono stylistykę dokumentu. W nawiasach kwadratowych dodano wyjaśnienia oraz uzupełnienia. Całość opatrzono niezbędnymi przypisami. Niestety, nie udało się dotrzeć do bliższych danych personalnych części spośród wymienionych w źródle funkcjonariuszy NKWD niższego szczebla.

Dokument jest przechowywany w Resortowym Archiwum Służby Bezpieczeństwa Ukrainy w Kijowie (fond 16, opis 1, jed. zb. 469, k. 86-94).

$* * *$

Ściśle tajne* $^{*}$

\section{DO KOMISARZA LUDOWEGO SPRAW WEWNĘTRZNYCH ZWIAZZKU SRR KOMISARZA BEZPIECZEŃSTWA PAŃSTWOWEGO I-EJ RANGI}

\section{tow.[arzysza] BERII Ł.[awrientija] P. [awłowicza]}

m.[iasto] MOSKWA.

Zgodnie z Waszymi dyrektywami co do śledztwa w sprawie zranienia, a później śmierci męża deputowanej Rady Najwyższej Związku S[ocjalistycznych] R[epublik] R[adzieckich], pisarki Wandy WASILEWSKIEJ ${ }^{52}$ - Mariana BOGATKO, syna Józefa, na miejsce do m.[iasta] Lwowa, delegowałem zast. [ępcę] komisarza ludowego spraw wewnętrznych U[kraińskiej] S[ocjalistycznej] R[epubliki] R[adzieckiej] tow.[arzysza] GORLINSKIEGO ${ }^{53}$ i specjalnego pełnomocnika NKWD USRR tow.[arzysza] WIERIETIENNIKOWA, którzy ustalili, co następuje:

* Ta uwaga jest skreślona. Zastapił ją odręczny dopisek po ukraińsku: „Ne tajemno [Jawne] 24/2-1719 23.04.[20]13 r.” Na lewym marginesie u góry dokumentu adnotacja: „Do akt” i nieczytelny podpis.

${ }^{52}$ Wanda Wasilewska została deputowaną Rady Związku Rady Najwyższej ZSRR w uzupełniających „wyborach”, które przeprowadzono na zaanektowanych ziemiach wschodnich II Rzeczypospolitej 24 III 1940 r. Kandydowała z miejskiego okręgu wyborczego nr 579 we Lwowie. W. Grosz, Kandydatka ziemi bez jarzma, „Czerwony Sztandar”, 20 III 1940, s. 3; Wybrańcy ludu do Rady Najwyższej ZSRR, „Czerwony Sztandar”, 29 III 1940, s. 1.

${ }^{53}$ Nikołaj Dmitrijewicz Gorlinskij (1907-1965), Ukrainiec, urodził się na wsi w powiecie sumskim (gubernia charkowska) w rodzinie robotnika-mechanika. Bardzo wcześnie osierocony, wychowywał się w domu dziecka. Ukończył szkołę cerkiewno-parafialna (1915-1917) i wieczorową szkołe partyjną II stopnia (1927-1928). W interesującym nas tutaj okresie - jako starszy major bezpieczeństwa państwowego - był od 7 XII 1938 r. do 22 VIII 1940 r. drugim zastępca komisarza ludowego spraw wewnętrznych Ukraińskiej SRR. N.W. Pietrow, Kto rukowodit organami gosbiezopasnosti. 1941-1954. Sprawocznik, Moskwa 2010, s. 303-304. 
19 marca b.[ieżącego] r.[oku] NKWD B[iałoruskiej] SRR telegraficznie powiadomił UNKWD ${ }^{54}$ Lwowa, że według zeznań członka organizacji „Zwiazek Walki Zbrojnej” ${ }^{55}$ ORŁA $^{56}$, onże ORZEŁ Zasław, syn Henryka - dom mieszkającej we Lwowie przy ul. Zadwórzańskiej ${ }^{57} \mathrm{nr} 49$ dentystki DOBROWOLSKIEJ ${ }^{58}$, stanowi lokal konspiracyjny członków organizacji „ZWZ” na hasło: „Jestem od Szura, chcę widzieć się z panną Wandą. W telegramie podano, że Wanda zamieszkuje, jakoby, u DOBROWOLSKIEJ, której to przy zwróceniu się [do niej] należy koniecznie powiedzieć: „Chcę widzieć się z Władkiem albo Janem" i w ten sposób będzie nawiązany kontakt z lwowskim ośrodkiem organizacji.

Naczelnik UNKWD tow.[arzysz] SIERGIJENKO ${ }^{59}$ polecił 19 III kierownikowi 2. Wydziału tow.[arzyszowi] DROZDIECKIEMU ${ }^{60}$ przeprowadzić w tej sprawie rozpoznanie, po czym dalsze posunięcia uzgodnić z nim.

${ }^{54}$ UNKWD (Uprawlenije Narodnogo komissariata wnutriennich dieł - Zarząd Komisariatu Ludowego Spraw Wewnętrznych [Obwodu Lwowskiego]).

${ }^{55}$ Związek Walki Zbrojnej (ZWZ) - polska konspiracyjna organizacja wojskowa powołana 13 XI 1939 r. W lutym 1942 r. przemianowana na AK.

${ }^{56}$ Nazwisko Orzeł jest wymieniane wśród grupki liderów polskiego podziemia w Brześciu nad Bugiem już w końcu 1939 r. Tenże konspirator (zatrudniony w przemyśle leśnym) po nawiązaniu kontaktów z „centrum dowódczym” we Lwowie realizował otrzymane tam zadanie zjednoczenia polskich grup podziemnych w ramach Polskiej Organizacji Wojskowej (POW). Dokonało się to na początku 1940 r. Organizacja ta podporządkowała sobie także Szare Szeregi w Brześciu, a wkrótce związała się z siatką ZWZ. R. Wnuk, „Za pierwszego Sowieta”. Polska konspiracja na Kresach Wschodnich II Rzeczypospolitej (wrzesień 1939czerwiec 1941), Warszawa 2007, s. 277-281.

57 Od 1992 r. nosi imię historyka Wołodymyra Antonowycza - w rejonie frankiwskim, między ulicami Stepana Bandery a Kulparkowska. W swojej historii była także Ogrodnicza oraz Sadownicka. W 1927 r. przemianowana została na Zadwórzańską - na pamiątkę bitwy z bolszewikami pod Zadwórzem 17 VIII 1920 r. Kolejne zmiany nazwy w 1946 r. i następnych latach. Zlokalizowana niedaleko dworca kolejowego (od ul. L. Sapiehy do ul. Kulparkowskiej). P. Włodek, A. Kulewski, Lwów. Przewodnik, Pruszków 2006, s. 290.

${ }^{58} \mathrm{~W}$ Ilustrowanym informatorze miasta Lwowa ze spisem miejscowości woj.[ewództwa] lwowskiego na rok 1939 (Lwów 1939) na s. 37 w wykazie lekarzy dentystów znajduje się następujący zapis: „Dobrowolska Natalia, Zadwórzańska 49, tel. 261-82”.

${ }^{59}$ Wasilij Timofiejewicz Siergijenko (1903-1982) ukończył w 1913 r. trzy klasy szkoły parafialnej, a w latach 1923-1924 - Wyższą Szkołę Robotniczo-Chłopskiej Armii Czerwonej. Jako major b.p. (od 14 III 1940 r. - starszy major b.p.) był zastępcą komisarza ludowego spraw wewnętrznych Ukraińskiej SRR i równocześnie naczelnikiem Zarządu NKWD Obwodu Lwowskiego (od 26 II 1940 r. do 26 II 1941 r.), co nadawało wysoką rangę tej placówce. Następnie kierował NKWD Ukraińskiej SRR (26 II 1941 - 29 VII 1943 r.). N.W. Pietrow, K.W. Skorkin, Kto rukowodit NKWD 1934-1941. Sprawocznik, red. N.G. Ochotin, A.B. Roginski, Moskwa 1999, s. 378-379.

${ }^{60}$ Pawieł Gawriłowicz Drozdieckij (1903-1979), Rosjanin. Urodził się w rodzinie chłopskiej w guberni witebskiej. Początkowo pracował na kolei. W organach bezpieczeństwa od października 1930 r. - najpierw w Karelskiej Autonomicznej SRR, a następnie w obwodzie leningradzkim. Po aneksji wschodniej Polski przez ZSRR jako starszy lejtnant bezpieczeństwa państwowego zatrudniony na stanowisku naczelnika 2 Wydziału Zarządu Bezpieczeństwa 
22 III [19]40 r. zastępca pełnomocnika operacyjnego 2. Wydziału UNKWD t. [owarzysz] SZAPRAN ustalił, że pod wskazanym adresem we Lwowie rzeczywiście mieszka lekarz dentystka DOBROWOLSKA. Przy tym t.[owarzysz] SZAPRAN ograniczył się do zewnętrznych oględzin domu, wskutek czego o zajmowaniu lokalu w tymże budynku przez deputowaną Rady Najwyższej ZSRR Wandę WASILEWSKA nic SZAPRAN nie wiedział.

Wobec nieefektywności podjętych kroków przez 2. Wydział, t.[owarzysz] SIERGIJENKO zlecił 30 III dalsze działania co do [obserwacji] tego domu naczelnikowi 3. Wydziału UNKWD t.[owarzyszowi] MAKAROWOWI ${ }^{61}$.

Na polecenie MAKAROWA kierownik sekcji 3. Wydziału t.[owarzysz] BOGDANOW sporządził plan operacji, który przewidywał wysłanie na rozpoznanie t.[owarzysza] KAZAKA do domu DOBROWOLSKIEJ, z wykorzystaniem znanego hasła. W przypadku niepowodzenia manewru $\mathrm{z}$ hasłem, plan uwzględniał urządzenie zasadzki w tym lokalu. Tej koncepcji t.[owarzysz] SIERGIJENKO nie zatwierdził i polecił t.[owarzyszowi] MAKAROWOWI zorganizować zwykłą zasadzkę.

Nacz.[elnik] 3. Wydziału t.[owarzysz] MAKAROW operację przewlekł, a 24 kwietnia podjął decyzję o jej przeprowadzeniu z wykorzystaniem „hasła”.

Nie dysponując wystarczajacym rozpoznaniem domu i dogłębnie nie przemyślawszy planu przygotowania operacji, t.[owarzysz] Makarow wyznaczył: zast.[ępcę] kier.[ownika] sekcji t.[owarzysza] ROZE, starszych pełnomocników operacyjnych BOWKUNOWA i BARBANA, pełnomocników operacyjnych JAKOWLEWA i KONSTANTINOWA oraz wywiadowcę KAZAKA, którym i powierzył operację.

Jak ustalono w śledztwie, t.[owarzysz] MAKAROW, wydzielonych do tej roboty współpracowników nie poinstruował, a ograniczył się do krótkich informacji o tym, czym jest operacja w lokalu konspiracyjnym, zupełnie nic nie powiedział o trybie praktycznego jej przeprowadzenia i nie udzielił żadnych

Państwowego w Zarządzie NKWD Obwodu Lwowskiego (od listopada 1939 r. do listopada 1940 r.). Na stopień kapitana b.p. awansowany 29 V 1940 r. i po pół roku przeniesiony do Kijowa, gdzie od listopada 1940 r. do marca 1941 r. był naczelnikiem 2 Wydziału NKWD Ukraińskiej SRR, a po rozdzieleniu tego resortu na NKWD i NKGB - naczelnikiem 3 Zarządu NKGB Ukraińskiej SRR (marzec-sierpień 1941 r.). N.W. Pietrow, op. cit., s. 343-344. ${ }^{61}$ Iwan Wasiljewicz Makarow (1906-1972). W latach 1938-1939 naczelnik Oddziału Kontrwywiadu w Zarządzie NKWD Obwodu Charkowskiego, następnie w obwodzie sumskim. Od września do listopada 1939 naczelnik grupy operacyjnej NKWD USRR w Borysławiu. Jako lejtnant b.p. do czerwca 1940 r. kierował Oddziałem Kontrwywiadu Wydziału Bezpieczeństwa Państwowego w Zarządzie NKWD Obwodu Lwowskiego, skąd przeniesiony został na takie samo stanowisko do Zarządu NKWD Obwodu Połtawskiego. Polska $i$ Ukraina w latach trzydziestych-czterdziestych XX wieku. Nieznane dokumenty $z$ archiwów służb specjalnych. Polskie podziemie 1939-1941, t. I: Lwów-Kołomyja-Stryj-Złoczów, Warszawa-Kijów 1998, s. 473; Polska i Ukraina w latach trzydziestych-czterdziestych XX wieku. Nieznane dokumenty $z$ archiwów stużb specjalnych, t. X: Rozkaz nr 001353. Operacja proskrypcyjna NKWD 1939-1941, Warszawa-Kijów 2020 (w druku). 
wskazówek o postępowaniu współpracowników w przypadku [napotkania] zbrojnego oporu. A przy tym, t.t.[owarzysze] BOWKUNOW i BARBAN, wiedząc o braku wytycznych, zgłosili t.[owarzyszowi] MAKAROWOWI propozycję dokonania rozpoznania, a [dopiero] potem zaczynać robotę. MAKAROW oświadczył, że wywiadowca KAZAK ma rozeznanie w tym domu i nie należy odkładać operacji.

Oświadczenie MAKAROWA o rozeznaniu KAZAKA nie odpowiadało rzeczywistości, albowiem ten ostatni niczego nie wiedział o lokatorach domu, przewidzianego do operacji.

O [terminie] rozpoczęcia operacji w nocy z 23 na 24 kwietnia t.[owarzysz] MAKAROW nikomu z kierownictwa UNKWD nie zameldował.

Kierowanie operacją MAKAROW powierzył zast.[ępcy] kier.[ownika] sekcji t.[owarzyszowi] ROZIE.

W nocy z 23 na 24 kwietnia, kiedy grupa już przybyła na miejsce, pracownicy BOWKUNOW i BARBAN znowu nalegali na to, ażeby operację odłożyć i zrobić rozpoznanie, ale kierujący nią t.[owarzysz] ROZA nie zgodził się z nimi.

Między godzinami pierwszą a drugą ROZA porozstawiał współpracowników wokół domu (który okazał się piętrową willa), sam przedostał się przez ogrodzenie i zaległ przy ogrodzenia z drutu, a wywiadowcę KAZAKA posłał do furtki w celu przejścia na dziedziniec i wywołania $\mathrm{z}$ domu DOBROWOLSKIEJ.

KAZAK, podszedłszy z ulicy do furtki, zadzwonił do domu i kiedy z okna na piętrze męski głos zapytał: „Kogo Wam trzeba?” - odpowiedział: „Dozorcę”.

Po kilku minutach w korytarzu frontowego [wejścia] zapaliło się światło i wyszli mężczyzna z kobieta, którzy następnie okazali się mężem i żoną DOBROWOLSKIMI.

DOBROWOLSKI zapytał: „Kogo potrzebujecie?”, na co KAZAK polecił [mu] odejść od furtki, oznajmiając, że chce rozmawiać z kobietą. DOBROWOLSKI odszedł, po czym KOZAK wypowiedział hasło: „Ja od Szura do panny Wandy”. DOBROWOLSKA wpuściła KAZAKA, zamykając za nim furtkę, w rezultacie czego stojący na ulicy dwaj współpracownicy, nie mogli, jak było zaplanowane, wejść w ślad za KAZAKIEM.

Mąż WASILEWKIEJ - BOGATKO, który wyszedł w tym momencie $\mathrm{z}$ domu, zapytał KAZAKA o przyczynę [tak] późnego przyjścia, na co KAZAK odpowiedział, że chce widzieć się z Wandą. BOGATKO poradził [mu] zgłosić się następnego dnia w godzinach ustalonych przez Wandę dla przyjęć interesantów ${ }^{62}$.

KAZAK próbował wytłumaczyć swoje późne przyjście tym, że jest przyjezdnym i prosto z pociagu, ale BOGATKO pozostał przy swoim i zaproponował przyjść nazajutrz.

${ }^{62}$ Kierownikiem biura deputowanej Wasilewskiej, mieszczącego się na parterze willi przy ul. Zadwórzańskiej 49, był Jerzy Ruszowski (1909-1984), jej znajomy z czasów działalności w ruchu socjalistycznym w Krakowie. J. Ruszowski, Byta jedna $z$ naszego pokolenia, w: Wanda Wasilewska we wspomnieniach..., s. 85-86; Wspomnienia Wandy Wasilewskiej..., s. 370. 
Widząc, że sam jeden wejść do domu nie może, KAZAK zawrócił z powrotem i, podchodząc do furtki, kilkakrotnie zagwizdał, dając sygnał współpracownikom znajdującym się na ulicy.

Usłyszawszy gwizdnięcia, Marian BOGATKO energicznie zatrzasnął drzwi i zaczą zapierać je. W tym momencie KAZAK, stojący przy stopniach [schodów do] frontowych drzwi, oceniając działania BOGATKI jako próbę ukrycia się i stawiania oporu, trzykrotnie strzelił przez szklane drzwi wejściowe, za którymi znajdował się BOGATKO. BOGATKO znikną za drzwiami, a za kilka minut pojawił się DOBROWOLSKI z narta w rękach, którą KAZAK uznał za karabin i ukrywszy się za występ domu, zażądał od DOBROWOLSKIEGO otwarcia drzwi.

W tym czasie ROZA, leżący za metalowym ogrodzeniem, rozkazał KAZAKOWI nie strzelać, a znajdujaccej się przy furtce DOBROWOLSKIEJ, polecił położyć się na ziemię, sam przelazł przez ogrodzenie, odemknął furtkę i wpuścił na podwórze dwóch uczestników operacji - BARBANA i KONSTANTINOWA.

KAZAK zażądał od DOBROWOLSKIEJ, aby wpuściła wszystkich do domu i okazał jej legitymację pracownika milicji na swoje nazwisko. DOBROWOLSKA poleciła stojącej w korytarzu siostrze Wandy WASILEWSKIEJ - Halinie WASILEWSKIEJ otworzyć drzwi i wpuścić do domu pracowników milicji, co i Halina WASILEWSKA zrobiła.

Dopiero wszedłszy do domu, pracownicy: ROZA, KAZAK, BARBAN i KONSTANTINOW, dowiedzieli się, że razem z DOBROWOLSKIMI zamieszkuje deputowana Rady Najwyższej ZSRR Wanda WASILEWSKA i że jej mąż Marian BOGATKO jest ranny. Tutaj od razu wezwali pogotowie ratunkowe i poinformowali UNKWD o zdarzeniu.

Przybyły niezwłocznie z pogotowiem ratunkowym lekarz przewiózł Mariana BOGATKE do szpitala, gdzie udzielono mu fachowej pomocy medycznej.

Podczas śledztwa wyszło także na jaw, że 30 marca br. [1940] naczelnik 3. Spec.[jalnego] Wydziału ${ }^{63}$ UNKWD MALCEW $^{64}$ otrzymał od zast.[epcy] nacz.[elnika] UNKWD MICHAJŁOWA polecenie - przeprowadzić rozpoznanie domu nr 49 przy ul. Zadwórzańskiej we Lwowie. Zadanie zostało tego samego dnia wykonane, a [wyniki] osobiście przekazane przez t.[owarzysza] MALCEWA na piśmie t. [owarzyszowi] MICHAJŁOWOWI. Przy tym dokładnie ustalono, że pod wskazanym adresem wspólnie z DOBROWOLSKIMI zamieszkuje deputowana Rady Najwyższej ZSRR Wanda WASILEWSKA i jej mąż Marian BOGATKO.

Zast.[epca] nacz.[elnika] UNKWD MICHAJŁOW kategorycznie zaprzecza, zarówno temu, że polecił MALCEWOWI przeprowadzić rozpoznanie, jak i że otrzymał 30 III [19]40 r. od MALCEWA wyniki rozpoznania.

${ }^{63} \mathrm{~W}$ gestii 3. Wydziału Specjalnego były rewizje, areszty i zewnętrzna obserwacja/ wywiad. ${ }^{64}$ J.I. Malcew był naczelnikiem 3. Wydziału Specjalnego do 30 V 1941 r. 
W toku dochodzenia nie został odnaleziony w UNKWD oryginał [dokumentu z] wykonanego 30 III przez 3. Spec.[jalny] Wydział rozpoznania, istnieje jedynie dokładna kopia i oryginalny raport wywiadowcy t.[owarzysza] NEJMANA.

Bioracy udział w operacji wywiadowca Piotr Piotrowicz KAZAK, pochodzaç ze w.[si] Sokal, rejon Kamień-Strumiłowski ${ }^{65}$, obwód lwowski, 1912 rok urodzenia, Ukrainiec, w 1937 roku był skazany przez polski sąd na 8 miesięcy więzienia za pobicie męża swojej siostry, w przeszłości kilkakrotnie wzywany na policję i przesłuchiwany w sprawie nielegalnego przejścia do ZSRR dwóch jego kolegów. Te dane zweryfikowane na miejscu.

W chwili przybycia oddziałów Armii Czerwonej na terytorium b.[yłej] Polski, KAZAK wspomagał jednostki RKKA ${ }^{66}$ przy [ich] przesuwaniu się, występując jako przewodnik, co jest potwierdzone w wydanym KAZAKOWI zaświadczeniu przez jednostkę wojskową nr 5597 z 24 IX 1939 roku.

W UNKWD Obwodu Lwowskiego KAZAK przeniósł się z Wydziału Kryminalnego $\mathrm{URKM}^{67}$ i wykonywał obowiązki wywiadowcy 3. [Kontrwywiadowczego] Wydziału UGB ${ }^{68}$.

Należy zauważyć, że obowiązkowe w takich przypadkach skrupulatne śledztwo nie było 24 kwietnia przeprowadzone na miejscu do końca, dlatego 30 kwietnia dodatkowo z udziałem eksperta medycyny sąowej został sporzadzony protokół oględzin miejsca zdarzenia i przesłuchani naoczni świadkowie.

W wyniku dochodzenia ustalono, że:

Naczelnik 3. Wydziału UNKWD - lejtnant bezpieczeństwa pań.[stwowego] t.[owarzysz] MAKAROW, nie meldujac kierownictwu UNKWD, naruszajacc wszystkie reguły czekistowskiej dyscypliny i pracy, wydał rozporządzenie o przeprowadzeniu nieprzygotowanej i nie przemyślanej operacji, osobiście nie wzią [w niej] udziału, a także nie poinstruował poprawnie współpracowników, uczestniczących w operacji.

Wskutek karygodnie niedbałego stosunku t.[owarzysza] MAKAROWA do służby podczas operacji został ranny i zmarł mąż deputowanej Rady Najwyższej ZSRR - Wandy WASILEWSKIEJ - Marian BOGATKO.

Zastępca kierownika sekcji 3. Wydziału UNKWD - sierżant bezpieczeństwa pań.[stwowego] ROZA, będąc wyznaczonym na dowódcę operacji, przejawił tchórzostwo i nieudolność, przerzucił cały ciężar operacji na niezbyt doświadczonego wywiadowcę KAZAKA - spośród miejscowych mieszkańców zachodniego obwodu, co doprowadziło do fiaska operacji.

\footnotetext{
65 Tak w dokumencie archiwalnym. Zapewne chodzi o wieś Sokole (obecnie w rejonie buskim, obwód lwowski). W okresie II RP należała ona do powiatu kamioneckiego w woj. tarnopolskim (nazwa powiatu od: Kamionka Strumiłowa - dziś Kamionka Bużańska w obwodzie lwowskim).

${ }^{66}$ RKKA (Rabocze-Kriestjanskaja Krasnaja Armija - Robotniczo-Chłopska Armia Czerwona).

${ }^{67}$ URKM (Uprawlenije rabocze-kriestjanskoj milicyi - Zarząd Robotniczo-Chłopskiej Milicji).

${ }^{68}$ UGB (Uprawlenije gosudartwiennoj biezopasnosti - Zarząd Bezpieczeństwa Państwowego).
} 
Wywiadowca UNKWD KAZAK stracił zimna krew w momencie operacji i otworzył zbyteczna, przedwczesna strzelaninę, w rezultacie której został śmiertelnie ranny Marian BOGATKO.

Tak więc stwierdzono w Lwowskim UNKWD brak kontroli wykonania, wyrażający się w tym, że w swoim czasie nie sprawdza się realizacji służbowych poleceń, przez co dopuszcza się do niekontrolowanego przeprowadzania nieprzygotowanych operacji, jak to w szczególności miało miejsce [w przypadku] naczelnika 3. Wydziału UNKWD t.[owarzysza] MAKAROWA, czego dotyczy dyrektywa tow.[arzysza] SIERGIJENKO.

Za głównego winowajcę niepowodzenia operacji i jej poważnych następstw uważam naczelnika 3. Wydziału UNKWD Obwodu Lwowskiego - lejtnanta bezpieczeństwa pań.[stwowego] MAKAROWA, który [został] zwolniony z pracy i zdegradowany z przeniesieniem do obwodu połtawskiego.

KAZAK - wywiadowca 3. Wydziału UNKWD aresztowany i przetrzymywany pod strażą od 24 kwietnia 1940 roku.

KOM[ISARZ] LUD[OWY] SPRAW WEWNĘTRZNYCH UKRAIŃSKIEJ SRR KOMISARZ BEZPIECZEŃSTWA PAŃSTWOWEGO 3 rangi /SIEROW/

\author{
№ \\ ”" czerwca $1940 \mathrm{r}$. \\ m.[iasto] Kijów \\ łs. - 69
}

${ }^{69}$ ł.s. - inicjały osoby, która prawdopodobnie przygotowała maszynopis pisma. 